Article

\title{
How Does Customer-Company Identification Enhance Customer Voice Behavior? A Moderated Mediation Model
}

\author{
Yang Ran $₫$ and Hao Zhou * \\ Business School, Sichuan University, Chengdu 610065, China \\ * Correspondence: zhouhao@scu.edu.cn
}

Received: 16 June 2019; Accepted: 7 August 2019; Published: 9 August 2019

check for updates

\begin{abstract}
For sustainable development, enterprises need to establish a good relationship with customers. Existing studies have pointed out that customer voice behavior is beneficial to maintaining and developing customer-firm relationships. Based on social identity theory, social exchange theory and self-efficacy theory, we propose a moderated mediation model to analyze the impact of customer-company identification on customer voice behavior, which includes complaints and suggestions for service improvement. Data were collected from 487 consumers in the online takeaway industry. The results show that customer-company identification has a positive impact on both complaints and service improvement suggestions, and customer commitment plays a mediating role in these relationships. Customer voice efficacy not only strengthens the positive effect of customer commitment on complaints and service improvement suggestions, but also strengthens the indirect effect of customer-company identification on two forms of customer voice behavior. Finally, theoretical contributions, managerial contributions and future directions are discussed.
\end{abstract}

Keywords: customer-company identification; customer voice behavior; customer commitment; voice efficacy; relationship marketing

\section{Introduction}

In the process of service production and delivery, customers are no longer bystanders; they often participate in it as "partial employees" [1,2]. In this changing role, customers will not only affect the production efficiency and service quality of enterprises, but also engage in active voluntary behavior, such as customer citizenship behavior [1,3].

As a type of customer citizenship behavior [1,4], customer voice behavior has attracted the attention of scholars. It is well recognized that the voices of consumers can bring a lot of benefits for enterprises, such as provide opportunities to correct errors [5], help to improve offerings and prevent future problems [6,7], and contribute to build close relationships between customers and service providers [8]. At the same time, with the rapid development of the Internet, consumers can choose to express their voices online. These voices can be shared on many online platforms, including social media sites, online shopping websites and so on [9]. Besides, the voices that consumers express online will play an important role in the products and services of enterprises $[10,11]$. Therefore, customer voice behavior can be expressed more conveniently in the Internet era, and consumers will be more willing to engage in voice behavior.

The concept of voice is first proposed by Hirschman [12] and has been developed rapidly in organizational behavior. Scholars have conducted a lot of research on the definition and classification of employee voice behavior, and its antecedent variables and outcome variables [13,14]. In the field of consumer behavior, scholars mainly regard customer voice as a component of customer citizenship 
behavior and refer to it as a type of customer complaining behavior $[8,15,16]$. Given the increasing understanding of the importance and connotation of voice behavior, scholars tend to study it as a multi-dimensional concept [17-19]. Referring to the viewpoint of Liang, Farh and Farh [18] and Béal and Sabadie [20], this study regards customer voice behavior as a two-dimensional concept: including consumers' complaints in dissatisfied situations and suggestions for service improvement. Both behaviors are regarded as positive and beneficial to the sustainable development of customer-firm relationships $[16,20,21]$. However, customers still hesitate to voice complaints or suggestions because these actions may bring risk and potential loss to them [22,23]. Hence, we need to gain a further understanding of the factors that can stimulate customer voice behavior.

As an important concept in relationship marketing, customer-company $(\mathrm{C}-\mathrm{C})$ identification reflects the emotional relationship between customers and enterprises, which is a crucial reason that customers are willing to maintain close relationships with enterprises [24,25]. This kind of emotional relationship can promote positive behavior on the part of customers, such as helping others, providing feedback and so on $[23,26,27]$. We suppose, therefore, that $C-C$ identification can be a predictor of customer voice.

To date, research on the relationship between $\mathrm{C}-\mathrm{C}$ identification and customer voice behavior is scant. Many scholars regard customer voice as a component of customer citizenship behavior in order to explore the relationship between $\mathrm{C}-\mathrm{C}$ identification and customer citizenship behavior, but there is a lack of differentiation on customer voice dimensions and exploration about the underlying mechanism of these two constructs [16,21]. This paper regards customer voice as a two-dimensional concept and chooses the online takeaway industry as a research context to explore the relationship between $\mathrm{C}-\mathrm{C}$ identification and customer voice behavior.

According to social identity theory and social exchange theory [28,29], when customers identify with a firm, they will regard themselves as part of the enterprise and want to help the enterprise achieve its goals. This kind of good interaction will stimulate customers' willingness to maintain this relationship, which is often called customer commitment [20]. Customers with a sense of commitment will perform positive actions to maintain a relationship with the enterprise. Thus, we assume the indirect effect of $\mathrm{C}-\mathrm{C}$ identification on customer voice behavior can be mediated by customer commitment. In addition, individual competence differences also can affect customer behavior; we consider voice efficacy as a moderator to explore the boundary conditions of the relationship between C-C identification and customer voice behavior.

In summary, this study presents a moderated mediation model to help us understand the underlying mechanism of $\mathrm{C}-\mathrm{C}$ identification on customer voice behavior. The model is then tested in an empirical study. Finally, the paper concludes with a discussion of the results, contributions and future research directions.

\section{Literature Review and Hypotheses}

\subsection{Customer Voice}

The concept of "voice" is initially put forward by Hirschman [12] in economics literature and has since been developed in organizational behavior literature. Van Dyne and Lepine [30] defined voice as a positive extra-role behavior, a definition which has been generally recognized in many research fields. Based on this definition, Liang, Farh and Farh [18] suggested two dimensions of employee voice, promotive voice and prohibitive voice, which have been applied in many studies. Promotive voice mainly involves new ideas or suggestions to improve organizational efficiency, while prohibitive voice indicates expressions of concern about work practices or employee behavior that are not favorable to the organization.

In early consumer behavior literature, customer voice behavior is regarded as a type of customer complaining behavior [15]. Customer voice refers to consumers' complaints to service providers when they encounter problems in the service process, and it is considered a reflection of customer 
dissatisfaction $[8,16]$. However, compared with other complaining behaviors (e.g., exit) when customers encounter dissatisfaction, customer voice provides opportunities for enterprises to correct errors and retain the customer-firm relationship; therefore, customer voice is regarded as a positive behavior [23,31]. Besides, customers often make suggestions to enterprises which can strengthen the relationship between the two parties [21,32]. Béal and Sabadie [20] have proposed that suggestions for service improvement can be regarded as a dimension of customer voice behavior.

Based on the above, this paper divides customer voice behavior into suggestions for improvement and complaints. First of all, these actions are positive extra-role behaviors on the part of customers, which is consistent with the definition of employee voice [30]. Secondly, customers participate in the service process of enterprises as partial employees. The behavior of customers to help enterprises improve service efficiency through suggestions is an example of promotive voice. When consumer complaints point out problems which can be detrimental to the development of enterprises, this behavior is consistent with the implications of prohibitive voice. Therefore, we assume that "promotive voice" and "prohibitive voice" also exist in the areas of marketing. Specifically, this paper focuses on customers' suggestion and complaint behavior.

\subsection{Customer-Company Identification}

Customers often come into the possession of a sense of identity in the process of interacting with enterprises. Bhattacharya and Sen [10] defined C-C identification as customers' perception of the close relationship between the enterprise and themselves. This perception comes from the comparison of the customers' identities with the enterprises' identities, from which the customer can obtain the psychological needs of self-identification and influence their consumption behaviors.

According to the theory of social identity $[29,33]$, people tend to define themselves by identifying with the groups they belong to and will strive to improve the group's status. The higher the level of $\mathrm{C}-\mathrm{C}$ identification, the more likely it is that consumers will consider themselves as part of the organization and show positive attitudes and behaviors to help the enterprise achieve its goals. For instance, studies have shown that C-C identification can positively affect customer loyalty and satisfaction $[34,35]$. C-C identification also positively affects customer purchase behavior $[25,36]$ and customer citizenship behavior [37,38].

In addition, customer voice behavior is also a method to help the enterprise. Specifically, complaint behaviors make enterprises aware of their own shortcomings and give them the opportunity to make up for these shortcomings. Customer suggestions for service improvement directly provide specific methods for improving the service efficiency of enterprises. In existing research, Wu and Tsai [27] have shown that improving C-C identification can increase customer suggestions and positive complaint behaviors, which are similar with the two dimensions of customer voice. Accordingly, this study predicts:

Hypothesis 1 (H1). Customer-company identification will be positively related to: (a) suggestions for service improvement and (b) complaint intentions.

\subsection{Customer Commitment}

Commitment is usually recognized as the major contribution to maintain a long-term relationship [39,40]. Many scholars view commitment as a three-component concept in organizational behavior. The three types of commitment include affective, normative and calculative commitment [41,42]. In relationship marketing, scholars focus more on the affective level of customer commitment and define it as consumers' willingness to maintain an ongoing relationship with a provider $[20,25,43]$.

Social exchange theory refers to when one party benefits from an interactive relationship, it will generate psychological motivation to maintain the relationship, and then to perform the behavior which is beneficial to the other party [28]. The interaction between customers and service providers in 
the process of service production and delivery also belongs to the category of social exchange [44]. Committed customers are more likely to perform cooperative behaviors because they want to build strong relationship with firms [36,37]. Liu and Mattila [45] also proved that customers with high affective commitment are more willing to help the enterprise improve its performance. As customer voice behavior is a positive behavior that is beneficial to firms, we argue that customer commitment positively affects customer voice behavior, and the positive relationship between customer commitment and customer voice behavior has been proven in some studies $[4,20,23]$.

C-C identification and customer commitment are often used to explain the relationship between customers and enterprises; the relationship between these two concepts has also attracted the attention of many scholars. Studies in organizational behavior have proven that organization identification is a predictor of employee commitment [46,47]. Research in marketing also indicates that identification is a key factor in establishing customer commitment [48,49]. Su et al. [25] and Hur, Kim and Kim [37] have shown that $\mathrm{C}-\mathrm{C}$ identification positively affects customer commitment through empirical research.

Based on the viewpoint of social identity theory and social exchange theory [28,29], C-C identification comes from the customers' perception of the similarity of their identities and the enterprises' identities. When customers perceive that their identity characteristics and values are similar to those of enterprises, they are more likely to equate enterprises with themselves, and to generate a sense of satisfaction and dependence on their products and service. These emotions can stimulate customer commitment, and then promote customers' positive behaviors to continue the relationship with enterprises.

From the definitions of these two concepts, customer-company identification indicates the cognition formed by consumers based on their understanding of various characteristics and information of enterprises. Customers will be willing to help the company when they identify with it, so the increase in C-C identification will stimulate customer commitment, and customer commitment reflects the behavior intentions of customers: when customer commitment is stronger, customers are more willing to express their voice behavior. Therefore, we suppose that customer commitment will play a mediating role between $\mathrm{C}-\mathrm{C}$ identification and customer voice behavior. On the basis of these arguments, this study predicts:

Hypothesis 2 (H2). The relationship between customer-company identification and: (a) suggestions for service improvement and (b) complaint intentions will be mediated by customer commitment.

\subsection{Voice Efficacy}

Kish-Gephart et al. [50] initially put forward the concept of "voice efficacy" on the basis of self-efficacy theory. Based on this idea, Duan et al. [51] developed the concept and defined voice efficacy as the extent to which individuals believe themselves capable of voicing effectively.

Although customer commitment reflects the willingness of consumers to voice, the voice behavior can bring risk and potential loss, so consumers may hesitate to voice considering these factors [22,23]. According to self-efficacy theory, individuals believe that they have the ability and skills to control events in life when they feel a high sense of efficacy [52]. Therefore, when the level of voice efficacy is high, customers will feel more capable of voicing, so customer behavior intentions can be better translated into voice behavior. When the level of voice efficacy is low, customers' expectations of the positive results of their voice can be reduced, so the positive relationship between commitment and voice behavior will be weakened.

The role of voice efficacy in promoting employee voice behavior has been confirmed in existing literature [51,53]. According to the analysis above, customer voice is essentially the derivation of employee voice behavior in marketing situations. We posit that consumers will be more likely to participate in suggestion and complaint behaviors when they feel that they have high-level voice efficacy. Therefore, this study predicts: 
Hypothesis 3 (H3). The relationship between customer commitment and: (a) suggestions for service improvement and (b) complaint intentions will be moderated by voice efficacy, such that customer commitment will have a stronger positive relationship with suggestions for service improvement and complaint intentions for those with high voice efficacy than for those with low voice efficacy.

As mentioned above, customers perform behavior intentions on the basis of cognition, and then show positive behavior, such as voice behavior. If the indirect effect of $C-C$ identification on customer voice behavior is mediated by customer commitment, the relationship between customer commitment and customer voice will be positively moderated by voice efficacy. Therefore, when the level of voice efficacy is high, the indirect effect of $\mathrm{C}-\mathrm{C}$ identification on customer voice will be enhanced. Accordingly, this study predicts:

Hypothesis 4 (H4). Voice efficacy will positively moderate the effect of the mediated relationship between customer-company identification and: (a) suggestions for service improvement and (b) complaint intentions through customer commitment.

The theoretical model of this research is shown in Figure 1.

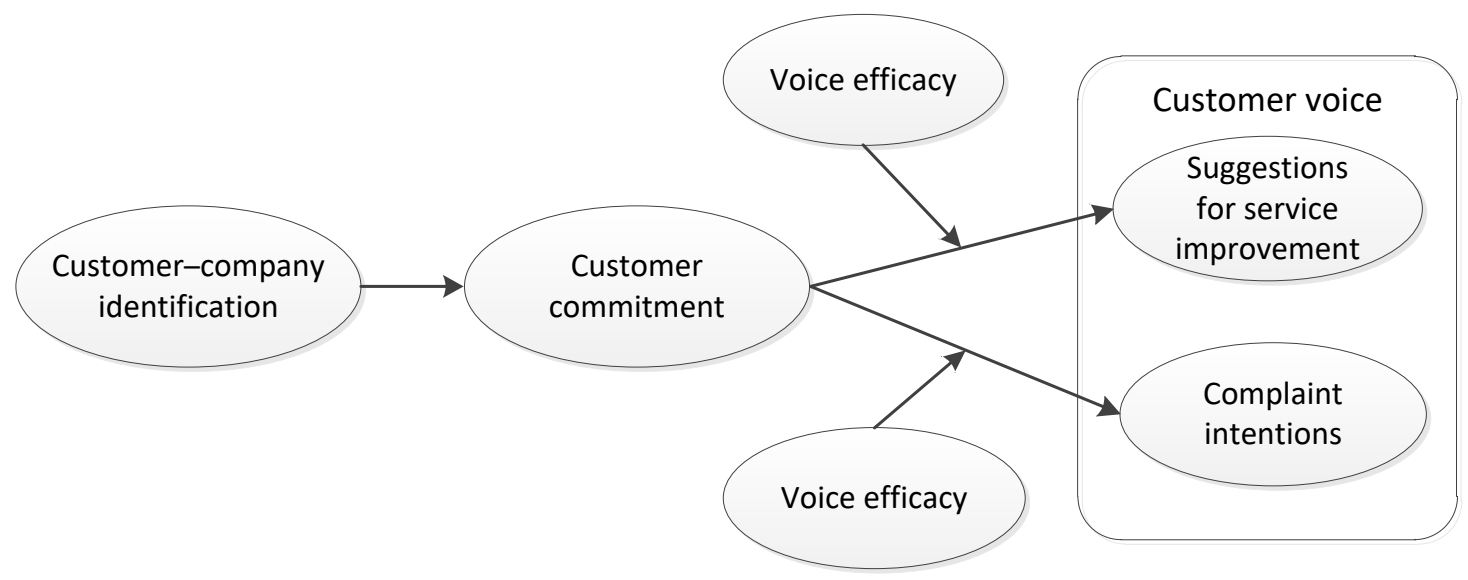

Figure 1. Theoretical model.

\section{Methodology}

\subsection{Measurement}

All constructs in this model were multiple-item scales adapted from existing scales. Customer-company identification was assessed using the five-item measurement from Homburg et al. [54], which was used to measure the identification of customers for travel agencies. Items for commitment were adapted from Garbarino and Johnson [39], who used a three-item scale to measure affective commitment. To measure customer voice behavior, we used the well-established scale by Béal and Sabadie [20] which was adapted from previous research (Chan et al. [55], Kalamas et al. [56]). The scales of voice efficacy were adapted from Duan, Kwan and Ling [51], who developed a three-item measurement to explore the relationship between voice efficacy and voice behavior. All the detailed scales are shown in Appendix A.

We followed the procedures suggested by Mullen [57] to ensure translation equivalence. All of the measures used seven-point Likert scales ( $1=$ "strongly disagree" to $7=$ "strongly agree").

\subsection{Sample}

To test the theoretical model, we chose the online takeaway industry as the research context for this study. As a combination of the Internet and catering, the online takeaway industry has become the fastest growing industry in China in recent years. Nowadays, the online takeaway market has 
over 300 million consumers and continues to grow rapidly [58]. Consumers can purchase meals, fruit, and other products online through a mobile app, and the special service staff (usually called "delivery people") will deliver the goods to a designated location by the appointed time. There are several reasons for choosing the online takeaway industry for the research context. First, according to Ahearne et al. [59], the context characteristics of C-C identification include frequency of product/service usage, the importance of company offerings to customers, and frequency of customer-company interaction. These characteristics all perform well in the context of the online takeaway industry. In addition, consumers can conveniently express their opinions and suggestions about the products and service, which can promote the intention of voice behavior.

According to the industry market report [58], college students comprise one of the major markets in the online takeaway industry. This study distributed 536 questionnaires to undergraduate students in their public courses at a university in China. Excluding the samples that had not used a takeaway platform, eventually we collected 487 usable questionnaires. The final sample consisted of 264 women (54.2\%) and 223 men (45.8\%), including 137 freshmen (28.1\%), 151 sophomores $(31 \%), 112$ juniors $(23 \%)$, and 87 seniors (17.9\%). On the frequency of service usage, $74.3 \%$ of respondents indicated that they used a takeaway platform no more than three times a week, while $25.7 \%$ of respondents used it at least four times a week. In terms of the use time with takeaway platforms, $376(77.2 \%)$ respondents noted that they had been users of takeaway platforms for at least six months, while $111(22.8 \%)$ respondents had used them for less than half a year.

\section{Results}

\subsection{Reliability and Validity Analyses}

We conducted reliability and validity analyses by using SPSS 22.0 and AMOS 23.0. As indicated in Table 1, all items can be reserved with factor loadings (EFA and CFA) are above 0.5 [60]. The model is appropriate to the data because the KMO (0.926) is greater than 0.6 [61]. Cronbach's alpha values for each of the measures range from 0.829 to 0.931 -all are above the 0.70 threshold for good reliability [60].

Table 1. Factor analysis, instrument validity and reliability.

\begin{tabular}{|c|c|c|c|c|c|c|c|}
\hline \multirow{2}{*}{ Variables } & \multirow{2}{*}{ Items } & \multirow{2}{*}{$\mathbf{M}$} & \multirow{2}{*}{ SD } & \multirow{2}{*}{$\begin{array}{c}\% \text { of } \\
\text { Variance }\end{array}$} & \multicolumn{2}{|c|}{ Loadings } & \multirow{2}{*}{$\begin{array}{l}\text { Cronbach's } \\
\text { Alpha }\end{array}$} \\
\hline & & & & & EFA & CFA & \\
\hline \multirow{5}{*}{$\begin{array}{l}\text { Customer-Company Identification } \\
\text { (CCI) }\end{array}$} & CCI1 & 5.18 & 1.167 & \multirow{5}{*}{21.748} & 0.879 & 0.860 & \multirow{5}{*}{0.902} \\
\hline & $\mathrm{CCI} 2$ & 4.98 & 1.249 & & 0.835 & 0.920 & \\
\hline & $\mathrm{CCI} 3$ & 4.95 & 1.320 & & 0.782 & 0.821 & \\
\hline & CCI4 & 4.90 & 1.267 & & 0.813 & 0.888 & \\
\hline & CCI5 & 4.11 & 1.607 & & 0.770 & 0.641 & \\
\hline \multirow{3}{*}{$\begin{array}{l}\text { Customer Commitment } \\
\text { (CC) }\end{array}$} & $\mathrm{CC} 1$ & 4.35 & 1.413 & \multirow{3}{*}{16.150} & 0.685 & 0.884 & \multirow{3}{*}{0.900} \\
\hline & CC2 & 4.63 & 1.258 & & 0.607 & 0.874 & \\
\hline & $\mathrm{CC} 3$ & 4.25 & 1.421 & & 0.757 & 0.843 & \\
\hline \multirow{3}{*}{$\begin{array}{l}\text { Voice Efficacy } \\
\text { (VE) }\end{array}$} & VE1 & 4.41 & 1.291 & \multirow{3}{*}{16.008} & 0.764 & 0.854 & \multirow{3}{*}{0.931} \\
\hline & VE2 & 4.46 & 1.287 & & 0.851 & 0.924 & \\
\hline & VE3 & 4.45 & 1.320 & & 0.852 & 0.943 & \\
\hline \multirow{3}{*}{$\begin{array}{l}\text { Suggestions for Service Improvement } \\
\text { (SSI) }\end{array}$} & SSI1 & 4.74 & 1.262 & \multirow{3}{*}{14.815} & 0.821 & 0.863 & \multirow{3}{*}{0.927} \\
\hline & SSI2 & 4.57 & 1.311 & & 0.747 & 0.910 & \\
\hline & SSI3 & 4.64 & 1.319 & & 0.806 & 0.928 & \\
\hline \multirow{3}{*}{$\begin{array}{l}\text { Complaint Intentions } \\
\qquad(\mathrm{CI})\end{array}$} & CI1 & 3.90 & 1.559 & \multirow{3}{*}{14.192} & 0.760 & 0.673 & \multirow{3}{*}{0.829} \\
\hline & CI2 & 4.43 & 1.460 & & 0.843 & 0.845 & \\
\hline & $\mathrm{CI} 3$ & 4.60 & 1.405 & & 0.829 & 0.861 & \\
\hline \multirow[t]{3}{*}{ Instrument Total } & \multicolumn{3}{|c|}{ Cumulative (\%) } & 82.912 & & & \multirow[t]{3}{*}{0.942} \\
\hline & & KMO & & 0.926 & & & \\
\hline & & -value & & 0.000 & & & \\
\hline
\end{tabular}

Notes: Item details for each construct are shown in Appendix $\mathrm{A} ; \mathrm{M}=$ mean; $\mathrm{SD}=$ standard deviation; $\mathrm{EFA}=$ exploratory factor analysis; CFA = confirmatory factor analysis; $\mathrm{KMO}=$ Kaiser-Meyer-Olkin. 
The results in Table 2 indicate a good composite reliability (CR) with all of the values exceeding 0.8. For the evaluation of convergent validity, with all factor loadings exceeding 0.5 and the average variances extracted (AVE) of each construct exceeding 0.5 , the results suggest adequate convergence [60]. As for discriminant validity, all square roots of the AVE are greater than the maximum inter-construct correlation (Max r), implying proper discriminant validity.

Table 2. Test of discriminant validity, convergent validity and composite reliability.

\begin{tabular}{cccccccccc}
\hline & CR & AVE & MSV & Max r & CCI & CC & VE & SI & CI \\
\hline CCI & 0.917 & 0.692 & 0.599 & 0.774 & $\mathbf{0 . 8 3 2}$ & & & & \\
CC & 0.901 & 0.752 & 0.442 & 0.665 & 0.774 & $\mathbf{0 . 8 6 7}$ & & & \\
VE & 0.934 & 0.824 & 0.442 & 0.665 & 0.567 & 0.665 & $\mathbf{0 . 9 0 8}$ & & \\
SSI & 0.928 & 0.811 & 0.406 & 0.637 & 0.560 & 0.622 & 0.637 & $\mathbf{0 . 9 0 1}$ & \\
CI & 0.838 & 0.636 & 0.341 & 0.584 & 0.355 & 0.405 & 0.455 & 0.584 & $\mathbf{0 . 7 9 7}$ \\
\hline
\end{tabular}

Notes: $\mathrm{CR}=$ composite reliability; AVE = average variances extracted; MSV = maximum shared variance; Max $\mathrm{r}=$ maximum inter-construct correlation; $\mathrm{CR}>0.8$; AVE $>0.5$; MSV $<\mathrm{AVE}$; the square root of the AVE is bold face diagonal.

Additionally, a set of confirmatory factor analyses (CFA) were used to assess construct validity through Amos 23.0. As shown in Table 3, the five-factor model provided a reasonable model fit $\left(\chi^{2}=476.69, \mathrm{df}=109, \mathrm{CFI}=0.949, \mathrm{TLI}=0.928, \mathrm{RMSEA}=0.051\right)$ while the four-factor and three-factor models fit poorly. The results indicate that the discriminant validity of the five-factor model is acceptable by comparing the baseline model fit to the fit of other models in Table 3.

Because all items in this study were self-reported, the problem of common variance may exist. Following the suggestion of Podsakoff et al. [62], we performed a single factor test in CFA. The results showed a poor model fit $\left(\chi^{2}=2743.46, \mathrm{df}=119, \mathrm{CFI}=0.636\right.$, TLI $=0.533$, RMSEA $\left.=0.130\right)$, which indicated that common variance had little influence on this study.

Table 3. Comparison of measurement models.

\begin{tabular}{cccccccc}
\hline Model & Factors & $\chi^{2}$ & df & $\chi^{2} / \mathbf{d f}$ & CFI & TLI & RMSEA \\
\hline Baseline & Five factors & 476.79 & 109 & 4.374 & 0.949 & 0.928 & 0.051 \\
Model & Four factors_SSI and CI were combined & 804.85 & 113 & 7.123 & 0.904 & 0.870 & 0.068 \\
Model 1 & Four factors -CCI and CC were combined & 823.09 & 113 & 7.284 & 0.902 & 0.867 & 0.069 \\
Model 2 & Three factors_SSI and CI were combined, & 1150.92 & 116 & 9.922 & 0.857 & 0.811 & 0.083 \\
Model 3 & CCI and CC were combined & 2743.48 & 119 & 23.054 & 0.636 & 0.533 & 0.130 \\
Model 4 & All five factors were combined & 273 \\
\hline
\end{tabular}

Notes: $\chi^{2}=$ chi-square; $\mathrm{df}=$ degree of freedom; $\mathrm{CFI}=$ comparative fit index; TLI = Tacker-Lewis index; RMSEA = root mean square error of approximation.

\subsection{Hypotheses Testing}

We used hierarchical regression analysis to test Hypotheses 1-3; the results are shown in Table 4 . First, we tested the effects of the independent variable ( $\mathrm{C}-\mathrm{C}$ identification) on the dependent variable (customer voice). After controlling for the effects of gender, grade, and use frequency, $\mathrm{C}-\mathrm{C}$ identification had a significant positive relationship with suggestions for service improvement $(\beta=0.541, p<0.01$, Model 2) and complaints intention $(\beta=0.354, p<0.01$, Model 6). Therefore, Hypothesis 1a and Hypothesis $1 \mathrm{~b}$ are supported.

Then, we tested the effect of the independent variable on the mediating variable (customer commitment). Results show that $\mathrm{C}-\mathrm{C}$ identification is significantly positively related to customer commitment ( $\beta=0.768, p<0.01$, Model 10). Finally, after adding $\mathrm{C}-\mathrm{C}$ identification and customer commitment into the regression model, customer commitment was positively related to both suggestions for service improvement $(\beta=0.465, p<0.01$, Model 3$)$ and complaint intentions $(\beta=0.326, p<0.01$, Model 7), and the coefficient of $\mathrm{C}-\mathrm{C}$ identification to suggestions for service improvement declined 
from $0.541(p<0.01)$ to $0.183(p<0.01)$, while the coefficient of $C-C$ identification to compliant intentions declined from $0.354(p<0.01)$ to $0.104(p>0.05)$. Based on the results above, customer commitment partially mediated the relationship between $\mathrm{C}-\mathrm{C}$ identification and suggestions for service improvement. Meanwhile, it fully mediated the relationship between $\mathrm{C}-\mathrm{C}$ identification and complaint intentions. Thus, Hypothesis $2 \mathrm{a}$ and Hypothesis $2 \mathrm{~b}$ are verified.

Hypothesis 3 proposed the moderating effect of voice efficacy; the interaction items of customer commitment and voice efficacy were mean-centered. Results showed that the interaction items have significant effects on both suggestions for service improvement $(\beta=0.086, p<0.01$, Model 4$)$ and complaint intentions $(\beta=0.111, p<0.01$, Model 8$)$. Therefore, Hypothesis 3a and Hypothesis $3 \mathrm{~b}$ are supported.

Table 4. Moderated regression analysis.

\begin{tabular}{|c|c|c|c|c|c|c|c|c|c|c|}
\hline & \multicolumn{4}{|c|}{ SSI } & \multicolumn{4}{|c|}{ CI } & \multicolumn{2}{|c|}{$\mathrm{CC}$} \\
\hline & Model 1 & Model 2 & Model 3 & Model 4 & Model 5 & Model 6 & Model 7 & Model 8 & Model 9 & Model 10 \\
\hline Gender & $0.173^{* *}$ & $0.086 *$ & $0.079 *$ & $0.080 *$ & 0.004 & -0.053 & -0.058 & -0.053 & -0.098 ** & 0.014 \\
\hline Grade & -0.087 & -0.030 & -0.022 & 0.010 & -0.028 & 0.009 & 0.014 & 0.043 & 0.138 * & -0.017 \\
\hline UF & $0.146^{* *}$ & 0.031 & 0.023 & 0.017 & 0.128 ** & 0.052 & 0.047 & 0.040 & $0.181^{* *}$ & 0.018 \\
\hline CCI & & $0.541 * *$ & $0.183 * *$ & $0.146 * *$ & & 0.354 ** & 0.104 & 0.076 & & 0.768 ** \\
\hline $\mathrm{CC}$ & & & $0.465 * *$ & $0.243^{* *}$ & & & 0.326 ** & 0.132 & & \\
\hline VE & & & & $0.389 * *$ & & & & $0.339 * *$ & & \\
\hline $\mathrm{CC} \times \mathrm{VE}$ & & & & $0.086^{* *}$ & & & & 0.111 ** & & \\
\hline $\mathbf{R}^{2}$ & 0.050 & 0.322 & 0.408 & 0.497 & 0.015 & 0.132 & 0.175 & 0.248 & 0.050 & 0.600 \\
\hline$\Delta \mathbf{R}^{2}$ & 0.050 & 0.272 & 0.086 & 0.089 & 0.015 & 0.117 & 0.042 & 0.074 & 0.050 & 0.550 \\
\hline $\mathbf{F}$ & $8.445^{* *}$ & $57.247^{* *}$ & $66.43^{* *}$ & $67.688^{* *}$ & 2.531 & $18.38^{* *}$ & $20.37^{* *}$ & $22.617^{* *}$ & $8.556^{* *}$ & $180.99 * *$ \\
\hline
\end{tabular}

To further assess the moderated mediating effect, this study used the general path analytic framework proposed by Edwards and Lambert [63]. The results are shown in Table 5, which indicate the indirect effect of the mediation model ( $\mathrm{C}-\mathrm{C}$ identification to customer commitment to suggestions for service improvement) was significantly different between the high voice efficacy group and the low voice efficacy group $(0.255-0.057=0.198, p<0.05)$. The indirect effects of the mediation model $(\mathrm{C}-\mathrm{C}$ identification to customer commitment to complaint intentions) was also significantly different between the two groups $(0.398-(-0.160)=0.558, p<0.01)$. Thus, Hypothesis $4 \mathrm{a}$ and Hypothesis $4 \mathrm{~b}$ are validated.

Table 5. Results of the moderated path analysis.

\begin{tabular}{ccccccc}
\hline & & \multicolumn{4}{c}{ X (CCI) $\rightarrow$ M (CC) $\rightarrow$ Y (SSI/CI) } \\
\cline { 3 - 7 } & & \multicolumn{2}{c}{ Stage } & \multicolumn{3}{c}{ Effect } \\
\cline { 3 - 7 } & & First & Second & Direct & Indirect & Total \\
\hline \multirow{2}{*}{ SSI } & High VE (+1 s.d.) & $0.646^{* *}$ & $0.395^{* *}$ & 0.094 & $0.255^{* *}$ & $0.349^{* *}$ \\
& Low VE (-1 s.d.) & $0.542^{* *}$ & 0.105 & $0.206^{*}$ & 0.057 & $0.263^{* *}$ \\
& Differences & $0.104^{* *}$ & $0.290^{*}$ & -0.112 & $0.198^{*}$ & 0.086 \\
\hline \multirow{2}{*}{ CI } & High VE (+1 s.d.) & $0.646^{* *}$ & $0.616^{* *}$ & $-0.325^{* *}$ & $0.398^{* *}$ & 0.072 \\
& Low VE (-1 s.d.) & $0.542^{* *}$ & $-0.296^{* *}$ & $0.383^{* *}$ & $-0.160^{* *}$ & $0.223^{* *}$ \\
& Differences & $0.104^{* *}$ & $0.911^{* *}$ & $-0.709^{* *}$ & $0.558^{* *}$ & $-0.151^{*}$ \\
\hline
\end{tabular}

Notes: $\mathrm{N}=487$, High VE $=$ mean +1 s.d., Low VE = mean -1 s.d; $\mathrm{X}$ represents independent variable; $\mathrm{M}$ represents mediator; Y represents dependent variable; s.d. = standard deviation; ${ }^{*} p<0.05,{ }^{* *} p<0.01$.

\section{Discussion}

\subsection{General Results}

As two dimensions of customer voice behavior, customer complaints and suggestion behavior often appear in the service process. This paper investigated the relationship between C-C identification and these customer behaviors on the basis of social identity theory. The results show that there is a 
positive correlation between $\mathrm{C}-\mathrm{C}$ identification and customer voice behavior, but customer commitment plays a partially mediating role between customer-company identification and suggestion behavior, while customer commitment plays a totally mediating role between customer-company identification and complaint behavior.

Furthermore, we tested the moderating effect of voice efficacy. The results indicate that voice efficacy has a positive moderating effect on the second stage (customer commitment to customer voice behavior) and the entire mediating effect in the concept model. The analysis results show that the degree of voice efficacy's moderating effect on the two kinds of customer voice behaviors is different; thus, the positive moderating effect of voice efficacy on customer complaints is stronger. A possible reason for this is that customers express their dissatisfaction by complaining, but this behavior may bring punishment to some people (e.g., service staff), and suggestion behavior is intended to express ideas about improving the service. Thus, complaint behavior may lead consumers to perceive more risks than suggestion behavior. When the level of personal competence perception is low, consumers will worry about the possible adverse consequences of complaint behavior and will be afraid to complain. When voice efficacy is high, this worry must be weakened, and consumers will pay more attention to the positive results of complaint behavior. As a result, voice efficacy has a more positive moderating effect on customer complaint behavior than suggestions do.

\subsection{Theoretical Contributions}

This paper chose two critical variables in relationship marketing ( $\mathrm{C}-\mathrm{C}$ identification and customer commitment) to explore the relationships between the two concepts and customer voice behavior, and voice efficacy was selected as moderator in a moderated mediation model. These findings contribute to the present research in several ways.

First, as a type of customer extra-role behavior, there are few direct studies on customer voice behavior. Although some scholars have discussed that consumer complaints and useful suggestions may manifest as customer engagement behaviors [64], we considered these two behaviors as the dimension of customer voice from a new theoretical perspective. This paper focused on customer voice behavior as a two-dimensional construct. From the perspective of organizational behavior, these results theoretically support dividing customer voice behavior into suggestion and complaint behavior. Furthermore, based on social identity theory, social exchange theory and self-efficacy theory, we explored the relationship between $\mathrm{C}-\mathrm{C}$ identification and customer voice behavior and its underlying mechanism, which extends the current understanding of customer voice.

Second, the results we found contribute to the present research on relationship marketing. This article has made a pioneering study of the relationship between $\mathrm{C}-\mathrm{C}$ identification and customer voice behavior, as well as its specific underlying mechanisms. In addition, we examined the relationship between $C-C$ identification and customer commitment, which validated the previous opinions $[25,48,49]$ and will help us to distinguish the relationship between the two concepts.

Third, previous studies have paid less attention to consumers' personal competence, while voice efficacy reflects individual perceptions of personal competence. This paper chose voice efficacy as a moderating variable to explore its moderating effect on the relationship between consumers and enterprises. The results showed that the difference of individual competence provides a boundary condition to explain the role of $\mathrm{C}-\mathrm{C}$ identification. The application of a moderating variable which responds to individual differences provides a theoretical contribution for future research in marketing.

\subsection{Managerial Contributions}

The results of this research offer some valuable management implications for enterprises. According to existing literature, customer complaints and suggestions for service improvement are useful to enterprises in identifying problems and improving service quality. Both types of customer voice are considered positive extra-role behaviors on the part of customers [23,27,31]. If enterprises can make rational use of customer voice, it will be beneficial to improving their competitiveness. Therefore, 
customer resources could be an effective way to improve enterprise performance. Enterprises should put more effort into promoting customer voice behavior.

Further, the results of this study showed that both $\mathrm{C}-\mathrm{C}$ identification and customer commitment have a positive relationship with customer voice, which is consistent with previous studies $[4,20,27]$. In order to stimulate customer voice behavior, enterprises can consider enhancing consumers' sense of identification and affective commitment. For example, improving the corporate image and increasing the interaction between salespeople and customers can effectively promote customer identification and commitment [59].

Moreover, efficacy theory indicates that performance accomplishments and vicarious experiences can affect individual perception of efficacy [52]. Thus, enterprises can enhance customers' voice efficacy in two ways. Performance accomplishments refer to the direct experience of an individual; if enterprises can provide timely feedback following customer complaints, the level of direct experience will be high for consumers. In addition, publicizing the accomplishments of other consumers can improve the vicarious experience of individuals.

\section{Limitations and Future Directions}

Several limitations exist in this study which can provide opportunities for future research. First, the cross-sectional data used in this research has its objective problems, although the single-factor test confirmed that common variance exerted little influence on data. Also, the respondents were all college students, which may cause the problem of generalization. Longitudinal data and multi-source data can be considered for future research.

Moreover, we chose the online takeaway industry as the research context to test the theoretical model, which may have some limitations. Whether the model can be applied to other industries and contexts needs to be confirmed in future research.

Finally, we used intention scales to measure customer voice behavior. Although previous studies have indicated that intentions may be an acceptable method of measuring consumer behaviors, further studies could collect actual behavior data.

Author Contributions: Conceptualization, Y.R. and H.Z.; Methodology, H.Z.; Investigation; Software, Y.R. and H.Z.

Funding: This research was funded by National Natural Science Foundation of China (71872119; 71472129), Sichuan University (skqx201503), and Sichuan Research Center of System Science and Corporate Development (Xq18B01).

Acknowledgments: All authors thank the editors and reviewers for their valuable comments.

Conflicts of Interest: The authors declare no conflict of interest.

\section{Appendix A}

Table A1. Measurement scales.

\begin{tabular}{|c|c|}
\hline \multicolumn{2}{|c|}{ Measures of Core Constructs } \\
\hline \multicolumn{2}{|c|}{ Customer-Company Identification } \\
\hline 1. & I strongly identify with this [company name]. \\
\hline 2. & I feel good to be a customer of this [company name]. \\
\hline 3. & I like to tell that I am a customer of this [company name]. \\
\hline 4. & This [company name] fits well to me. \\
\hline & I feel attached to this [company name]. \\
\hline \multicolumn{2}{|c|}{ Suggestions for Service Improvement } \\
\hline & $\begin{array}{l}\text { I put a lot of effort into expressing my point of view about what should be the [company } \\
\text { name]'s priorities. }\end{array}$ \\
\hline 2. & I am ready to provide suggestions to the [company name] for improving the service outcomes. \\
\hline 3. & I am highly involved in deciding how the services should be provided by the [company name]. \\
\hline
\end{tabular}


Table A1. Cont.

\begin{tabular}{|c|c|}
\hline \multicolumn{2}{|c|}{ Measures of Core Constructs } \\
\hline \multicolumn{2}{|c|}{ Complaint Intentions } \\
\hline & $\begin{array}{l}\text { If there is a service failure: } \\
\text { I would complain to the [company name]. } \\
\text { I would not hesitate to complain if I think it is warranted to do so. } \\
\text { I would ask to talk to my customer adviser to explain the reason of the problem. }\end{array}$ \\
\hline \multicolumn{2}{|r|}{ Customer Commitment } \\
\hline & $\begin{array}{l}\text { I am proud to be a customer of this [company name]. } \\
\text { I care about the long-term success of this relationship. } \\
\text { I am willing "to go the extra mile" to remain a customer of this [company name]. }\end{array}$ \\
\hline \multicolumn{2}{|c|}{ Voice Efficacy } \\
\hline & $\begin{array}{l}\text { Proactively develop and make suggestions for issues that may influence the [company name]. } \\
\text { Proactively suggest new projects which are beneficial to the [company name]. } \\
\text { Proactively voice out constructive suggestions that help the [company name] reach its goals. }\end{array}$ \\
\hline
\end{tabular}

\section{References}

1. Groth, M. Customers as Good Soldiers: Examining Citizenship Behaviors in Internet Service Deliveries. J. Manag. 2005, 31, 7-27. [CrossRef]

2. Bowen, D.E.; Schneider, B.; Kim, S.S. Shaping service cultures through strategic human resource management. Handb. Serv. Mark. Manag. 2000, 1, 439-454.

3. Tat Keh, H.; Wei Teo, C. Retail customers as partial employees in service provision: A conceptual framework. International J. Retail. Distrib. Manag. 2001, 29, 370-378. [CrossRef]

4. Bove, L.L.; Pervan, S.J.; Beatty, S.E.; Shiu, E. Service worker role in encouraging customer organizational citizenship behaviors. J. Bus. Res. 2009, 62, 698-705. [CrossRef]

5. Randi, P. Relationship marketing can mitigate product and service failures. J. Serv. Mark. 2003, 17, 37-52. [CrossRef]

6. Ahmad, S. Service failures and customer defection: A closer look at online shopping experiences. Manag. Serv. Qual. Int. J. 2002, 12, 19-29. [CrossRef]

7. Assaf, A.G.; Josiassen, A.; Cvelbar, L.K.; Woo, L. The effects of customer voice on hotel performance. Int. J. Hosp. Manag. 2015, 44, 77-83. [CrossRef]

8. Lacey, R. How customer voice contributes to stronger service provider relationships. J. Serv. Mark. 2012, 26, 137-144. [CrossRef]

9. Stevens, J.L.; Spaid, B.I.; Breazeale, M.; Jones, C.L.E. Timeliness, transparency and trust: A framework for managing online customer complaints. Bus. Horiz. 2018, 61, 375-384. [CrossRef]

10. Jin, J.; Liu, Y.; Ji, P.; Kwong, C. Review on Recent Advances in Information Mining From Big Consumer Opinion Data for Product Design. J. Comput. Inf. Sci. Eng. 2019, 19, 010801. [CrossRef]

11. Yang, B.; Liu, Y.; Liang, Y.; Tang, M. Exploiting user experience from online customer reviews for product design. Int. J. Inf. Manag. 2019, 46, 173-186. [CrossRef]

12. Hirschman, A.O. Exit, Voice and Loyalty: Responses to Decline in Firms, Organizations and States; Harvard University Press: Cambridge, MA, USA, 1970.

13. Morrison, E.W. Employee voice and silence. Ann. Rev. Organ. Psychol. Organ. Behav. 2014, 1, $173-197$. [CrossRef]

14. Wilkinson, A.; Barry, M.; Morrison, E. Toward an integration of research on employee voice. Hum. Resour. Manag. Rev. 2019. [CrossRef]

15. Boote, J. Towards a comprehensive taxonomy and model of consumer complaining behaviour. J. Consum. Satisf. Dissatisfaction Complain. Behav. 1988, 11, 140-151.

16. Crutchfield, T.N. Individual service providers versus the firm: Where do customer loyalties lie? Serv. Mark. Q. 2008, 29, 19-44. [CrossRef] 
17. Hagedoorn, M.; Yperen, N.W.V.; Vliert, E.V.D.; Buunk, B.P. Employees' reactions to problematic events: A circumplex structure of five categories of responses and the role of job satisfaction. J. Organ. Behav. 1999, 20, 309-321. [CrossRef]

18. Liang, J.; Farh, C.I.C.; Farh, J.L. Psychological Antecedents of Promotive and Prohibitive Voice: A Two-Wave Examination. Acad. Manag. J. 2012, 55, 71-92. [CrossRef]

19. Van Dyne, L.; Ang, S.; Botero, I.C. Conceptualizing Employee Silence and Employee Voice as Multidimensional Constructs. J. Manag. Stud. 2003, 40, 1359-1392. [CrossRef]

20. Béal, M.; Sabadie, W. The impact of customer inclusion in firm governance on customers' commitment and voice behaviors. J. Bus. Res. 2018, 92, 1-8. [CrossRef]

21. Bettencourt, L.A. Customer voluntary performance: Customers as partners in service delivery. J. Retail. 1997, 73, 383-406. [CrossRef]

22. Krefting, L.A.; Powers, K.J. Exercised voice as management failure: Implications of willing compliance theories of management and individualism for de facto employee voice. Empl. Responsib. Rights J. 1998, 11, 263-277. [CrossRef]

23. Bove, L.L.; Robertson, N.L. Exploring the role of relationship variables in predicting customer voice to a service worker. J. Retail. Consum. Serv. 2005, 12, 83-97. [CrossRef]

24. Bhattacharya, C.B.; Sen, S. Consumer-Company Identification: A Framework for Understanding Consumers' Relationships with Companies. J. Mark. 2003, 67, 76-88. [CrossRef]

25. Su, L.; Swanson, S.R.; Chinchanachokchai, S.; Hsu, M.K.; Chen, X. Reputation and intentions: The role of satisfaction, identification, and commitment. J. Bus. Res. 2016, 69, 3261-3269. [CrossRef]

26. Roos, I. Switching processes in customer relationships. J. Serv. Res. 1999, 2, 68-85. [CrossRef]

27. Wu, W.Y.; Tsai, C.H. The empirical study of CRM: Consumer-company identification and purchase intention in the direct selling industry. Int. J. Commer. Manag. 2007, 17, 194-210. [CrossRef]

28. Blau, P. Exchange and Power in Social Life; John Wiley: New York, NY, USA, 1964.

29. Brewer, M.B. The social self: On being the same and different at the same time. Personal. Soc. Psychol. Bull. 1991, 17, 475-482. [CrossRef]

30. Van Dyne, L.; Lepine, J.A. Helping and Voice Extra-Role Behaviors: Evidence of Construct and Predictive Validity. Acad. Manag. J. 1998, 41, 108-119. [CrossRef]

31. Spake, D.F.; Beatty, S.E.; Brockman, B.K.; Crutchfield, T.N. Consumer comfort in service relationships: Measurement and importance. J. Serv. Res. 2003, 5, 316-332. [CrossRef]

32. Cossío-Silva, F.J.; Revilla-Camacho, M.Á.; Vega-Vázquez, M.; Palacios-Florencio, B. Value co-creation and customer loyalty. J. Bus. Res. 2016, 69, 1621-1625. [CrossRef]

33. Tafel, H.; Turner, J. The Social Identity Theory of in Tergroup Behaviorec; Worchel, S., Austin, W.G., Eds.; Psy-Chology of Intergroup Relations, Nelson Hall: Chicago, IL, USA, 1986.

34. Fatma, M.; Khan, I.; Rahman, Z. CSR and consumer behavioral responses: the role of customer-company identification. Asia Pac. J. Mark. Logist. 2018, 30, 460-477. [CrossRef]

35. Huang, M.H.; Cheng, Z.H.; Chen, I.C. The importance of CSR in forming customer-company identification and long-term loyalty. J. Serv. Mark. 2017, 31, 63-72. [CrossRef]

36. Karaosmanoglu, E.; Altinigne, N.; Isiksal, D.G. CSR motivation and customer extra-role behavior: Moderation of ethical corporate identity. J. Bus. Res. 2016, 69, 4161-4167. [CrossRef]

37. Hur, W.M.; Kim, H.; Kim, H.K. Does customer engagement in corporate social responsibility initiatives lead to customer citizenship behaviour? The mediating roles of customer-company identification and affective commitment. Corp. Soc. Responsib. Environ. Manag. 2018, 25, 1258-1269. [CrossRef]

38. Wu, S.H.; Huang, S.C.T.; Tsai, C.Y.D.; Lin, P.Y. Customer citizenship behavior on social networking sites: The role of relationship quality, identification and service attributes. Internet Res. 2017, 27, 428-448. [CrossRef]

39. Garbarino, E.; Johnson, M.S. The Different Roles of Satisfaction, Trust and Commitment in Customer Relationships. J. Mark. 1999, 63, 70-87. [CrossRef]

40. Morgan, R.M.; Hunt, S.D. The commitment-trust theory of relationship marketing. J. Mark. 1994, 58, 20-38. [CrossRef]

41. Meyer, J.P.; Allen, N.J. Commitment in the Workplace: Theory, Research and Application; Sage: Thousand parks, CA, USA, 1997.

42. Meyer, J.P.; Allen, N.J.; Smith, C.A. Commitment to organizations and occupations: Extension and test of a three-component conceptualization. J. Appl. Psychol. 1993, 78, 538. [CrossRef] 
43. Gustafsson, A.; Johnson, M.D.; Roos, I. The effects of customer satisfaction, relationship commitment dimensions, and triggers on customer retention. J. Mark. 2005, 69, 210-218. [CrossRef]

44. Vaughan, B.; Renn, R. Customer service citizenship behavior: Bridging the employee-customer relationship. Adv. Manag. Organ. Qual. 1999, 4, 151-186.

45. Liu, S.Q.; Mattila, A.S. "I want to help" versus "I am just mad" how affective commitment influences customer feedback decisions. Cornell Hosp. Q. 2015, 56, 213-222. [CrossRef]

46. Marique, G.; Stinglhamber, F. Identification to Proximal Targets and Affective Organizational Commitment. J. Pers. Psychol. 2011, 10, 107-117. [CrossRef]

47. Wiener, Y. Commitment in organizations: A normative view. Acad. Manag. Rev. 1982, 7, 418-428. [CrossRef]

48. Fullerton, G. How commitment both enables and undermines marketing relationships. Eur. J. Mark. 2005, 39, 1372-1388. [CrossRef]

49. Keh, H.T.; Xie, Y. Corporate reputation and customer behavioral intentions: The roles of trust, identification and commitment. Ind. Mark. Manag. 2009, 38, 732-742. [CrossRef]

50. Kish-Gephart, J.J.; Detert, J.R.; Treviño, L.K.; Edmondson, A.C. Silenced by fear: The nature, sources, and consequences of fear at work. Res. Organ. Behav. 2009, 29, 163-193. [CrossRef]

51. Duan, J.; Kwan, H.K.; Ling, B. The role of voice efficacy in the formation of voice behaviour: A cross-level examination. J. Manag. Organ. 2014, 20, 526-543. [CrossRef]

52. Bandura, A. Self-efficacy: Toward a unifying theory of behavioral change. Psychol. Rev. 1977, 84, 191. [CrossRef]

53. Edakkat Subhakaran, S.; Dyaram, L. Individual disposition and manager behaviour on employee upward voice: mediating role of voice self-efficacy. Int. J. Organ. Anal. 2018, 26, 875-889. [CrossRef]

54. Homburg, C.; Wieseke, J.; Hoyer, W.D. Social identity and the service-profit chain. J. Mark. 2009, 73, 38-54. [CrossRef]

55. Chan, K.W.; Yim, C.K.; Lam, S.S. Is customer participation in value creation a double-edged sword? Evidence from professional financial services across cultures. J. Mark. 2010, 74, 48-64. [CrossRef]

56. Kalamas, M.; Laroche, M.; Makdessian, L. Reaching the boiling point: Consumers' negative affective reactions to firm-attributed service failures. J. Bus. Res. 2008, 61, 813-824. [CrossRef]

57. Mullen, M.R. Diagnosing measurement equivalence in cross-national research. J. Int. Bus. Stud. 1995, 26, 573-596. [CrossRef]

58. iiMedia. 2017-2018 China Online Catering Food Market Research Report. Available online: http://www. iimedia.cn/60449.html (accessed on 5 August 2019).

59. Ahearne, M.; Bhattacharya, C.B.; Gruen, T. Antecedents and consequences of customer-company identification: Expanding the role of relationship marketing. J. Appl. Psychol. 2005, 90, 574-585. [CrossRef] [PubMed]

60. Hair, J.F.; Black, W.C.; Babin, B.J. Multivariate Data Analysis; Pearson Prentice Hall: Upper Saddle River, NJ, USA, 2006; pp. 1-816.

61. Moslehpour, M.; Yumnu, S. The mediating effect of quality and prestige on the relationship between brand globalness and purchase likelihood of HTC mobile phone. Int. Bus. Res. 2014, 7, 94. [CrossRef]

62. Podsakoff, P.M.; MacKenzie, S.B.; Lee, J.Y.; Podsakoff, N.P. Common method biases in behavioral research: A critical review of the literature and recommended remedies. J. Appl. Psychol. 2003, 88, 879. [CrossRef] [PubMed]

63. Edwards, J.R.; Lambert, L.S. Methods for integrating moderation and mediation: A general analytical framework using moderated path analysis. Psychol. Methods 2007, 12, 1. [CrossRef] [PubMed]

64. Van Doorn, J.; Lemon, K.N.; Mittal, V.; Nass, S.; Pick, D.; Pirner, P.; Verhoef, P.C. Customer engagement behavior: Theoretical foundations and research directions. J. Serv. Res. 2010, 13, 253-266. [CrossRef]

(C) 2019 by the authors. Licensee MDPI, Basel, Switzerland. This article is an open access article distributed under the terms and conditions of the Creative Commons Attribution (CC BY) license (http://creativecommons.org/licenses/by/4.0/). 